\title{
Low Molecular Weight Cyclin E
}

National Cancer Institute

\section{Source}

National Cancer Institute. Low Molecular Weight Cyclin E. NCI Thesaurus. Code C128284.

Proteolytically processed forms of cyclin E proteins, which are specifically generated in tumors that overexpress cyclin E proteins. 